\title{
A New Perspective on Faculty Status
}

\section{Fred E. Hill and Robert Hauptman}

The authors contend that if librarians are to deserve faculty status they must comply with standards of excellence that are similar to those of the instructional faculty. The teaching roles of librarians at Evergreen State College and St. Cloud State University are cited. The roles of medical school faculty are discussed and the similarities to library faculty are viewed as worthy of further study.

If librarians want faculty status, they must assume the concomitant responsibilities. Among these education, research, and publication are primary considerations.-Virgil F. Massman

o many surveys, essays, and diatribes have been published concerning faculty status that, at first, another might appear superfluous. Here is one more, though, with an unusual point of view. The contention of this article is not whether librarians should be accorded faculty status, but rather whether they deserve it, and more importantly, what they should do with it once it has been bestowed.

In order to determine whether faculty status continues to be an issue of high priority, the authors conducted a literature review and considered more than seventy documents, many of them published quite recently. Additionally, the authors prepared a short questionnaire that was sent to one hundred academic librarians chosen at random from the American $\mathrm{Li}$ brary Directory. These librarians represent both colleges and universities, and their professional activities cover a broad range, e.g., technical services, public services, special collections, archives, and government documents. ${ }^{1}$ Fifty-one of the one hundred questionnaires were re- turned. Thirty-one respondents (61 percent) hold faculty status, and twenty (39 percent) do not. Thirty-four respondents (67 percent) indicate that faculty status is important to them, and seventeen (33 percent) state that it is not. Finally, thirtythree respondents (65 percent) believe that the general issue of faculty status for librarians is important, seventeen (33 percent) think that it is not, and one ( 2 percent) has no preference. The logical conclusion drawn from the literature review and survey is that faculty status, under whatever guise, continues to be an important library issue.

Certain assumptions concerning instructional faculty are normally taken for granted. Faculty are masters of substantive knowledge in a specific discipline, they teach, they ostensibly perform research and publish the results, they frequently hold earned doctorates, they are self-governing, they have nine-month contracts (except for chairpersons), they have academic freedom, and they are eligible for tenure. Often, librarians with faculty status have not mastered a discipline, do not teach, do not do research, do not possess an earned doctorate, do not hold nine-month contracts, must work a thirtyfive to forty hour week, and invariably earn less than their colleagues in other departments. $^{2}$

Fred E. Hill is an instructional developer and teacher and Robert Hauptman is a reference librarian and teacher. Both are in Learning Resources Services at St. Cloud State University, St. Cloud, Minnesota 56301. 
Is the holder of a B.S. in anthropology and an M.L.S. the intellectual or political equal of a colleague whose credentials include a Ph.D. in physics? We doubt it. This difference has been circumvented semantically. Campuses accommodate teaching faculty and nonteaching faculty, an unwarranted situation, at least for traditionalists. The ultimate result of all of this status maneuvering is that librarians often benefit from the privileges accorded to faculty without bearing the concomitant responsibilities.

From the beginning of the faculty status movement, and until fairly recently, proselytizers for faculty status have used a formidable array of often specious and selfserving arguments in order to convince colleagues and administrators that librarians and teaching faculty perform essentially the same tasks, and therefore should be accorded the same privileges. For example, reference librarians teach; but technical service librarians, curators, and computer specialists do not. In reality, even reference people do not teach. They may briefly instruct, generally concerning procedures, but they do not impart indepth, substantive knowledge on an ongoing basis. David Peele articulates this extreme point of view in a recent essay in The Journal of Academic Librarianship, but even he hedges a bit. ${ }^{3}$ So what usually exists is a campus divided between teaching and nonteaching faculty. This primary distinction is then further compounded by secondarily dividing library faculty into those who ostensibly teach (reference personnel) and those who do not. In some cases, the former are accorded faculty status, while the latter are not. This semantic quibbling results primarily in divisiveness among colleagues, and feelings of unfairness, inferiority, and inadequacy. Recently, the negative aspects of this have become apparent to both librarians and administrators. Today there is a shift away from faculty status for librarians. Thomas English points out that no members of the Association of Research Libraries have recently granted faculty status to librarians, and at least two schools have changed from faculty status to other systems. ${ }^{4}$

Even this alteration in faculty status atti- tude is somewhat self-serving. Librarians are doing the right deed (i.e., not expecting faculty status), but for the wrong reason; they no longer univocally advocate faculty status, not because they believe that they do not deserve it, but rather because they frequently cannot fulfill promotion and tenure requirements. In addition, those who do have it are frequently faced with the daily worry of whether they are going to lose it because they do not perform as "real faculty." And, interestingly, now that "almost 79 percent of academic libraries ... have some sort of faculty status," it is no longer appropriate.

The endless discussions about faculty status miss two important points: neither all libraries nor all librarians are the same. There are libraries and librarians that contribute to the academic process in essentially the same way as traditional faculty. Consider the program at Evergreen State College (Olympia, Washington) in which librarians have the opportunity to rotate assignments with faculty from other departments. The librarian becomes a teacher-researcher; the faculty member becomes a librarian. This exchange is made for one quarter every three years. ${ }^{6}$ Granted, this is hardly a regular teaching load, but it does encourage librarians to assume traditional faculty obligations, that is, to make new discoveries and to disseminate them through publication and teaching. There may be similar programs at other colleges and universities.

The St. Cloud State University library (St. Cloud, Minnesota) emphasizes both teaching and service. The library is a learning resources center that not only contains print and nonprint collections but also offers expertise in such nontraditional library services as database searching, interactive video production, curriculum design and development, satellite communications and instruction, as well as assisting in meeting demands of various university-related promotional efforts. In addition, the library (Learning Resources Services) has its own academic program offered through the Center for Information Media and the College of Education. Thus, the LRS faculty perform all the typical library functions and also perform the 
multiple service functions: they teach regular classes in their areas of expertise, they do research, and they publish the results, partly because they choose to, and partly because they are expected to, just like every faculty member on campus. They are evaluated professionally just like all other faculty. Furthermore, many hold doctorates and nine-month contracts. There is virtually no difference between an LRS faculty member and any other faculty member at St. Cloud State University.

Like Evergreen State College, St. Cloud State University provides another possibility whereby librarians can truly be faculty members. The LRS thrives and survives because of its unique structure, which is patterned after the medicalschool model. ${ }^{7,8}$ If one were to visit a medical school, the salient feature would be the structure. Faculty members teach, do research, and publish, but also participate in applied medicine. They see patients, prescribe, operate, and cure. Interestingly, they perform a service function not unlike those performed by LRS faculty. The value of the function is irrelevant in this context, because both sets of faculty do that which they are assigned to do. One may remove a gall bladder, and the other may produce a sophisticated annotated bibliography or codesign and produce a visualized presentation on gall bladder removal. Ultimately, they both teach what they have practiced.

In the early days, both librarians and doctors learned their professions through practice. Prior to 1876 , there were no college or university library-education programs, so learning through apprenticeship was mandatory. Early medical and library schools employed teachers who simultaneously practiced what they taught. Ironically, medical educators were criticized for this and administrators eventually tried to raise salaries in order to lure clinicians away from part-time practice to full-time education. In the modern period, education for doctors has come full circle, and the medical-school model insists that at least some of the clinicians at any given institution do three things: practice, teach, and conduct research. Education for librarianship, on the other hand, has slowed down in its development, and most educators are not practitioners.

Medical schools employ many kinds of faculty, each contributing in his or her own way to the furtherance of medicine. These faculty, by requirement, function as part of a team, and the school administration judiciously selects faculty who will provide instructional coverage of what is practiced in the center."

The LRS faculty at St. Cloud State University, functioning in an environment like the medical school, practice their profession and teach that practice to others. Because they teach what they practice daily their instruction reflects reality, and their students profit exceedingly. Concurrent with the instructional demands are the demands of research and publishing. Moreover, the LRS faculty are afforded an opportunity for sabbatical growth. At this writing six of our faculty have either just returned from, are on now, or will be shortly going on sabbatical leave. These sabbaticals are both service related and instructional. One professor is presently in England teaching museology to students enrolled in an international student program. Another may soon be teaching Spanish in a similar program in Costa Rica. Still another is finishing a Ph.D. in instructional design.

The medical-school model structure allows the St. Cloud State University library to be a learning resources center, with its multiple-format collection and its variety of faculty preparation. The diversity of the collection and faculty becomes a highly visible and measurable asset to the university, and the LRS and its faculty have some genuine assurances of their value to the institution.

There have been recent instances of graduate library-school closing, partially as a result of resource reallocation, and probably partially because of some reduction in their perceived value to the academic institution. This may lead some librarians to worry that faculty status and tenure are in jeopardy. Can it also be inferred that university leaders who terminate library schools on their campuses, for whatever reason, tend to minimize the 
contributions of librarianship generally? Certainly the opinions held by university administrators will be reflected in the policies and procedures that govern information systems in higher education. If these opinions denigrate the value of librarians holding faculty status it is possible that faculty status for librarians is doomed.

We believe that the purpose of an academic library is to store and retrieve information in order to facilitate the learning demands of users. Information is information regardless of format, and the exclusion of formats is detrimental to the patron. If one needs information it is significantly better to get it quickly and locally if possible. The medical-school model makes it possible to combine the strengths of the appropriate technologies. Libraries that offer information in multiple formats and that also offer teaching expertise whether in bibliographic instruction, new technologies, database searching, or other curricula may very well be the only ones in the future in which librarians hold faculty status, equally and with high value placed upon their worth by their campus colleagues and administrators.

Libraries do not necessarily need their own academic library school for their members to qualify as teaching faculty. In our information society there are many instructional-support courses that could be developed and taught by library faculty. These courses would contribute to the learning process on campus. Librarians must only possess the creative desire and energy to offer such courses.

Thus, our position is that there are conditions under which a librarian deserves faculty status, and these are precisely the same conditions that obtain for any faculty member at an institution: teaching, researching, and publishing. If tenure and promotion decisions for librarians are based on the same criteria used for other faculty, then the librarian must be accorded the same status.

We suggest an investigation of libraries that use the medical-school model in order to discover its generic and specific values to the host institution. Instead of repetitive surveys of traditional libraries, librarians, faculty, and faculty status, we recommend observing those environments in which library faculty perform as teaching faculty.

Ultimately, college and university administrators determine which faculty do or do not receive faculty status. It if is in the best interest of the organization for librarians to have faculty status then they will-provided, of course, they earn it. This model, we believe, is critical for the examination and implementation of faculty status.

\section{REFERENCES AND NOTES}

1. The seventeen colleges include Amherst, Concordia, Lewis-Clark, Berea, and Colorado; the eighty-three universities include San Diego, Yale, Drake, Johns Hopkins, Rutgers, Ohio State, Vanderbilt, Brown, and East Texas State.

2. Virgil F. Massman, Faculty Status for Librarians (Metuchen, N.J.: Scarecrow, 1972).

3. David Peele, "Librarians as Teachers: Some Reality, Mostly Myth," The Journal of Academic Librarianship, 10:267-70 (Nov. 1984).

4. Thomas G. English, "Librarian Status in the Eighty-Nine U.S. Academic Institutions of the Association of Research Libraries: 1982," College \& Research Libraries 44:199-211 (May 1983).

5. John DePew, "The ACRL Standards for Faculty Status: Panacea or Placebo," College \& Research Libraries 44:407-13 (Nov. 1983).

6. Mary M. Huston, "Research in a Rotating Librarian/Faculty Program." College \& Research Libraries News 46:13-15 (Jan. 1985).

7. Dwight F. Burlingame, Dennis C. Fields, and Anthony C. Schulzetenberg, The College Learning Resource Center (Littleton, Colo.: Libraries Unlimited, 1978).

8. John G. Berling, "The Technology of Learning Resources Services in Higher Education." Educational Media and Technology Yearbook 1985. (Littleton, Colo.: Libraries Unlimited, 1985), p.75-80.

9. Thomas B. Turner, Fundamentals of Medical Education (Springfield, Ill.: Charles C. Thomas, 1963), p.19-28. 